\title{
RELATIONSHIP BETWEEN SCRIPTS INTERRUPTIONS AND CONSUMERS AFFECTIVE JUDGEMENTS IN USERS OF A UNIVERSITY CAFETERIA
}

\author{
Fernando Juárez, Alba Patricia Roa, Ángela María Guerra \\ Universidad Pedagógica y Tecnológica de Colombia - Tunja, Colombia
}

\begin{abstract}
This study analyzes the relationship among various types of script interruptions and affective judgments of satisfaction and quality for users of a university cafeteria. It replicates the study carried out in Spain by Falces, Sierra, Briñol and Horcajo (2002). A questionnaire on satisfaction and quality service, developed by Falces, et al. (2002), was used. In terms of satisfaction, unsolved or unsuccessfully solved errors and obstacles leaded to more negative judgments than interruptions with a positive outcome and distractions were located in an intermediate position. Errors and obstacles both with a positive or negative solution differed among them; distractions differed from all other categories. This finding is different from the results obtained in the Spanish sample where no difference was found between obstacles and errors with a negative outcome and where distractions did not differ from other categories. Concerning quality service, distractions received the lowest score. The most significant differences were found between distractions and obstacles and between obstacles and errors. This finding also differs from the Spanish results where such categories show a similar pattern in terms of satisfaction.
\end{abstract}

Keywords: Scripts, Satisfaction, Quality, Consumer.

\section{RESUMEN}

Se analizó la relación existente entre diferentes tipos de alteración del guión y los juicios afectivos de satisfacción y calidad, en usuarios de una cafetería universitaria, replicando en Colombia el estudio realizado en España por Falces, Sierra, Briñol y Horcajo (2002). A 120 usuarios de la cafetería de la Universidad Pedagógica y Tecnológica de Colombia, se les aplicó el cuestionario de satisfacción y el de calidad del servicio, desarrollados por Falces, et al. (2002). En cuanto a satisfacción, los errores y obstáculos, sin resolución o con resolución negativa, provocaron juicios más negativos que las interrupciones con resultado positivo, ocupando las distracciones una posición intermedia. Los errores y los obstáculos, ambos con resolución positiva o negativa, se diferenciaron entre sí; las distracciones se diferenciaron de todas las categorías. Esto difiere de lo obtenido en la muestra española, donde no existieron diferencias entre los obstáculos y los errores, con resolución negativa, y donde las distracciones no originaron diferencias con otras categorías. En cuanto a calidad, las distracciones obtuvieron la menor puntuación; encontrándose las diferencias más significativas entre la distracción y el obstáculo, y entre el obstáculo y el error. Esto también difiere de la muestra española, donde dichas categorías muestran un patrón similar a lo obtenido en cuanto a la satisfacción.

Palabras Clave: Guión mental, Satisfacción, Calidad, Consumidor.

Schemas are mental structures (Arcas \& Cano, 1999) containing information about people, objects, actions, and events (Rumelhart \& McClelland, 1992) stored as general and specific knowledge (Rumelhart, 1984). Scripts are schematic mental representations (Johnson-Laird, 1980) made up of

Fecha recepción: 22/03/2007 - Fecha aceptación: 30/05/2007

Mail Address: Fernando Juárez

E-mail: fernando_juarez2@yahoo.com

Avenida carrera 45, no. 94-27, apartamento 301 Bogotá, Colombia causal chains of events, saved in the episodic memory and result-driven (Schank \& Abelson, 1977). Scripts allow individuals to plan actions, anticipate events (García, 1997) and be involved in specific situations (Ruiz, 1997).

Our behavior is considered to be, in its most part, of a consumption nature (Quintanilla, 1999). It is a social, symbolic and psychological fact (Berne, Pedraja, \& Rivera, 1977) that shapes our relationships (Gil, Feliu, \& Lajeunesse, 2004). A 
consumer performs different purchase scripts (Arellano, 1993) and while doing so he processes a large amount of information (León \& Olabarría, 1991), makes decisions and engages in a physical activity (Schiffman \& Lazar, 1996). Such scripts lead to different behavior models (León \& Olavaria, 1991) that represent the search of the product (Gil, et al., 2004).

Nonetheless, inconsistencies between the script and the actual result trigger both a physiological activation and an emotional response (Mandler, 1984). Such inconsistencies are called script interruptions and include: a) obstacles to terminate an action or start the next one; b) errors or inappropriate termination of an action without achieving the script goal and c) distractions or unexpected events activating new scripts and diverting the individual's attention away from the script in progress (Schank \& Abelson, 1977). Consumer judgments, rooted in these interruptions, greatly determine consumer satisfaction with products (Certo, 2001) while generating various effects in memory (Bower, Black, \& Turner, 1979). Thus, distractions and obstacles are better recalled than errors because the former affect the script sequence while the latter do not necessarily do so (Davidson \& Jergovic, 1996).

Many factors related to purchasing processes are known (Schiffman \& Lazar, 1996) and some works have focused on consumers' attitude towards the service they receive (see Mazo, Martínez, Ramos, \& Peiró, 2002; Zeithaml, Parasuraman, \& Berry, 1995). However, plenty of questions still remain about the consumers' decision making process (Múgica \& Ruiz, 1997). Survival of services depends on this process (Salvador, 2004) and consumer satisfaction is a good predictor of adherence (Caminal, 2001) and loyalty to the service supplier (Mazo, et al., 2002).

Consumer satisfaction has been traditionally associated to (1) communication between service providers and customers and skills perception by customers (Gattinara, Ibacache, Puente, Giaconi, \& Caprara, 1995); (2) the treatment received (Bronfman, López, Magis, \& Rutstein, 2003); (3) the size of the establishment (Barranco, 2002); (4), the product added value (Di Mare, 1992; Horovitz, 1992; Luna, 2001) or to (5) staff burnout levels (Garman, Corrigan, \& Morris, 2002). For restaurants in the hotel industry, consumer satisfaction is associated to product quality and to staff personality traits like kindness, professionalism and degree of service customization, to mention only but a few factors (Varela, Prat, Voces, \& Rial, 2006). So, staff training on social relationships skills is most important (Gea, Hernán, Jiménez, \& Cabrera, 2001).

An aspect of interest is that customer satisfaction is a function of the consumption experience as well as of previous expectations about the product or service (Hayes, 1999). In turn, customer expectations reflect previous experiences (Kotler, 1996). This latter fact was verified in Spain and Paraguay where customer satisfaction was determined by a non fulfillment of expectations (Salvador, 2005b). Script interruptions result in a non fulfillment of expectations since one of the main features of scripts is an anticipation of future events which, in the case of interruptions, would not take place and, therefore, access to results or benefits would not be possible, at least in the expected form. At universities, satisfaction depends on reception of these benefits (Salvador, 2005a).

On the other hand, consumer satisfaction is important when assessing service rendering (Williams, 1994) because quality is only achieved if service provides satisfaction (Zeithaml, et al., 1995). Quality is also assessed using customer perceptions of business as a global view that influences his/her perception of prices, products and services (Soler, Llobel, Frías, \& Rosel, 2006). Perceived service quality at a university restaurant depends on the products features, agility of service, comfort of facilities and customer service (Sierra, Falces, Ruiz, \& Alier, 2003). Consequently, it could be said that quality depends on the perceived outcome (Vázquez, Díaz, \& Rodríguez, 1997) and this, in turn, partially depends on script interruptions that took place.

Relations between script interruptions (Schank and Abelson, 1977) and memory has been studied by Falces, Sierra, Briñol, and Horcajo (2002). These Spanish researchers carried out a study using judgments about interruptive situations in a consumer context. Participants were asked to make satisfaction judgments about situations that reflected seven different kinds of script interruptions. The situations were related to the restaurant script. They also asked the participants to which extent these interruptions represented a high quality establishment. Investigators designed a list of situations reflecting script interruptions (obstacles, errors and distractions) proposed by Schank and Abelson (1977). These authors concluded that situations blocking action sequence (obstacles) lead to more extreme satisfaction responses than those situations in which actions are completed with inappropriate or unexpected results (errors). For quality evaluation of the restaurant, this pattern is repeated. Findings also suggested that the most prominent recall of obstacles and distractions could be explained by the intensity of emotional responses they produce. On the other hand, interruptions blocking script action sequence (obstacles) were reported to contain more information about the positive quality of a given context (in this case, high quality of a restaurant). This means that the blockage effect must be considered, additionally, relevant as an informative cue about the context assessed by consumers.

Up to now, ties between script interruptions and consumer judgments of satisfaction and quality have only been studied in European university contexts. The study by Falces, et al., (2002) aroused interest to replicate it in other contexts. Thus, the present study is aimed at analyzing the relation between different types of script interruptions and affective judgments on satisfaction and quality in a Colombian university cafeteria context, considering eventual cultural differences between Colombian and Spanish populations. 


\section{METHOD}

\section{Paricipants}

This study was carried out in two phases: an initial phase to evaluate satisfaction and a second stage to evaluate quality. lior cvery phase 60 participants were chosen (total sample of 120 individuals). Participants wore regular uscrs of the Universidad Pedagógica y Tecnológica de Colombia cafeteria, located in the city of Tunja. The average age of the sample was 23.5 , 17 bcing the minimum and 30 bcing the maximum. The number of participants is similar to the study by Falces, et al., (2002) where 63 students were included in the first phase and 57 in the second one.

\section{Instruments}

The questionnaire designed by Falces, et al. (2002) was used to measure consumer satisfaction in relation to script interruptions. This tool contains 21 unusual situations likely to happen in a university cafeteria. 'l'hese situations reflect seven categories of script interruptions: a) $\mathrm{S} 1$ : successfully solved obstacle, b) S2: successfully solved error, c) S.3: unsuccessfully solved obstacle d) S4: unsuccessfully solved error, c) S5: Obstacle, f) S6: Frror, g) S7: Distraction. A 7 point J ilkcrt-likc scale ranging from "(1) very negative" to "(2) very positive" was provided for every sinuation to indicate the extent of satisfaction with the outcomc. Additionally, participants indicated if they had expericnecd any of the 21 situations listed.

To cvaluate how representative these situations were of a high quality cafetcria another questionnaire was used, also designed by lialces, et al. (2002), containing the same situations (21) and categories in the previous checklist. Again a 7 point $]$.ikert-like scalc ranging from "(1) not representative at all" to "(7) very representative" was applied.

\section{Procedure}

The inclusion criterion for this sudy was regular users of the cafeteria scrvices in terms of frequency of visits. Selected participants visited the cafeteria on a daily basis. The goals of this study were explained to participants and they decided to take part voluntarily. Questionnaires were administered in a room next to the cafetcria and participants were divided in groups of 6 people maximum during a period of time ranging from 5 to 8 minutes, following the procedure indicated by lialces etal. (2002).

During the first phase (satisfaction assessment) an initial questionnaire was administered to 60 participants. In the sccond phase (quality represcntation) a sccond questionnaire was administered to 60 other participants. This two-phasc design, with different participants for each phase, mirrors the study by l’alces, et al. (2002).

\section{RESULTS}

Satisfaction with scriptinterroptions

Descriptive statistics corresponding to the satisfaction assessment phase are shown in Table 1. Categories with the highest scores are $\$ 2$ (successfully solved error) with a means scorc of $4.93(\mathrm{SD}=1.39$ ) and $\mathrm{S} 1$ (successfully solved obstacle) with a means score of $4.65(\mathrm{SD}=1.40)$. $\mathrm{S} 1$ and $\mathrm{S} 2$ show a significant difference from the rest of categories. Category $\mathrm{S} 7$ (Distraction) was locatcd in an intermediatc position with an average of $3.33(\mathrm{SD}=1.27)$. The other catcgorics obtaincd lower scores $\$ 4$ being the lowest score category (unsuccessfully solved error) with a means score of 1.88 $(\mathrm{SI}=1.26)$.

Tablc1. Descriptive statistics for satisfaction with soript intermotions

\begin{tabular}{lcccc}
\multicolumn{1}{c}{ Categories } & Min & Max & $\bar{X}$ & $S D$ \\
\hline S4: Error-unsuccessfully solved & 1.00 & 7.00 & 1.88 & 1.26 \\
S6: Error & 1.00 & 5.00 & 2.31 & 1.10 \\
S5: Obstacle & 1.00 & 7.00 & 2.47 & 1.39 \\
S3: Obstacle-unsuccessfully solved & 1.00 & 7.00 & 2.78 & 1.29 \\
S7: Distraction & 1.00 & 6.67 & 3.33 & 1.27 \\
S1: Obstacle-Successfully solved & 1.00 & 7.00 & 4.65 & 1.40 \\
S2: Error-Successfully solved & 1.00 & 7.00 & 4.93 & 1.39 \\
\hline
\end{tabular}

Situations and dimensions they belong to as well as the frequency and the percentage of peoplc who had cxpericnecd each situation are shown in Table 2. Results showed that the least frequent situation was number 2 with a low percentage of affirmative answcrs (13.3\%) followed by situation $15(16.7 \%)$. The most frequent situations were number $14(86.7 \%)$, number $5(83.3 \%)$, number $21(80 \%)$, number $18(78.3 \%)$, number $13(76.7 \%)$ and number $10(75 \%)$. In table 2 a Chisquarc analysis is also presented to verify if participants' distribution, according to their experience or not of situations asked, was random. Questions 1,3,8,11, 16 and 20 show a random distribution ( $\mathrm{p} \geq 0.05$ ) while questions $2,4,7,9,12,15$, 17 and 19 correspond to situations with significant higher frequencies for option "No" ( $<<0.05)$. Questions 5, 6, 10, 13, 14,18 and 21 correspond to situations with significant higher frequency in option "Yes" ( $p<0.05)$.

Next, a T test was used to determine whether questions with significant differences in terms of occurrence answers, also showed difference in means. The results of this analysis are prescntcd in Table 3. Only questions 2 (Error), 7 and 15 (successfully solved obstacle) showed to be significant. Thus, no differences were detected between the answers of those people who have expericnced the situations and those who have not, except for questions 2, 7 and 15 that represent situations that, significantly, have not been experienced by most of the participants as it is observed in Table 2 . 
Table 2. $\chi 2$ analysis for situations occurrence

\begin{tabular}{|c|c|c|c|c|c|c|c|c|c|c|c|}
\hline Question & $\begin{array}{c}\text { Occurrence } \\
\text { Option }\end{array}$ & $\begin{array}{c}F \\
\text { observed }\end{array}$ & $\%$ & $\begin{array}{c}F \\
\text { expected }\end{array}$ & $p$ & Question & $\begin{array}{c}\text { Occurrence } \\
\text { Option }\end{array}$ & $\begin{array}{c}F \\
\text { Observed }\end{array}$ & $\%$ & $\begin{array}{c}F \\
\text { expected }\end{array}$ & $p$ \\
\hline \multirow[t]{2}{*}{1 (S 7) } & Yes & 28 & 46.7 & 30 & 0.699 & $12(\mathrm{~S} 4)$ & Yes & 18 & 30 & 30 & 0.003 \\
\hline & No & 32 & 53.3 & 30 & & & $\mathrm{No}$ & 42 & 70 & 30 & \\
\hline \multirow[t]{2}{*}{$2(\mathrm{~S} 6)$} & Yes & 8 & 13.3 & 30 & 0.000 & 13 (S 7) & Yes & 46 & 76.7 & 30 & 0.000 \\
\hline & $\mathrm{No}$ & 52 & 86.7 & 30 & & & $\mathrm{No}$ & 14 & 23.3 & 30 & \\
\hline \multirow[t]{2}{*}{$3(\mathrm{~S} 3)$} & Yes & 22 & 36.7 & 30 & 0.052 & 14 (S 5) & Yes & 46 & 86.7 & 30 & 0.000 \\
\hline & $\mathrm{No}$ & 38 & 63.3 & 30 & & & $\mathrm{No}$ & 14 & 13.3 & 30 & \\
\hline \multirow[t]{2}{*}{$4(\mathrm{~S} 4)$} & Yes & 12 & 20 & 30 & 0.000 & $15(\mathrm{~S} 1)$ & Yes & 10 & 16.7 & 30 & 0.000 \\
\hline & No & 48 & 80 & 30 & & & No & 50 & 83.3 & 30 & \\
\hline \multirow[t]{2}{*}{$5(\mathrm{~S} 5)$} & Yes & 50 & 83.3 & 30 & 0.000 & $16(\mathrm{~S} 6)$ & Yes & 23 & 38.3 & 30 & 0.092 \\
\hline & $\mathrm{No}$ & 10 & 16.7 & 30 & & & No & 37 & 61.7 & 30 & \\
\hline \multirow[t]{2}{*}{$6(\mathrm{~S} 5)$} & Yes & 45 & 75 & 30 & 0.000 & 17 (S 3 ) & Yes & 12 & 20 & 30 & 0.000 \\
\hline & No & 15 & 25 & 30 & & & No & 48 & 80 & 30 & \\
\hline \multirow[t]{2}{*}{7 (S 1$)$} & Yes & 13 & 21.7 & 30 & 0.000 & $18(\mathrm{~S} 2)$ & Yes & 47 & 78.3 & 30 & 0.000 \\
\hline & No & 47 & 78.3 & 30 & & & $\mathrm{No}$ & 13 & 21.7 & 30 & \\
\hline \multirow[t]{2}{*}{$8(\mathrm{~S} 2)$} & Yes & 25 & 41.7 & 30 & 0.245 & $19(\mathrm{~S} 6)$ & Yes & 19 & 31.7 & 30 & 0.006 \\
\hline & No & 35 & 58.3 & 30 & & & $\mathrm{No}$ & 41 & 68.3 & 30 & \\
\hline \multirow[t]{2}{*}{$9(\mathrm{~S} 2)$} & Yes & 13 & 21.7 & 30 & 0.000 & $20(\mathrm{~S} 3)$ & Yes & 38 & 63.3 & 30 & 0.052 \\
\hline & $\mathrm{No}$ & 47 & 78.3 & 30 & & & $\mathrm{No}$ & 22 & 36.7 & 30 & \\
\hline \multirow[t]{2}{*}{$10(\mathrm{~S} 7)$} & Yes & 45 & 75 & 30 & 0.000 & $21(\mathrm{~S} 1)$ & Yes & 48 & 80 & 30 & 0.000 \\
\hline & $\mathrm{No}$ & 15 & 25 & 30 & & & $\mathrm{No}$ & 12 & 20 & 30 & \\
\hline \multirow[t]{2}{*}{$11(\mathrm{~S} 4)$} & Yes & 33 & 55 & 30 & 0.519 & & & & & & \\
\hline & $\mathrm{No}$ & 27 & 45 & 30 & & & & & & & \\
\hline
\end{tabular}

Table 3. T test to determine satisfaction means differences for questions that were significant in terms of occurrence

\begin{tabular}{|c|c|c|c|c|c|c|c|c|c|}
\hline Question & Occurrence Option & $\bar{X}$ & $T$ & $p$ & Question & Occurrence Option & $\bar{X}$ & $T$ & $p$ \\
\hline \multirow[t]{2}{*}{$2(\mathrm{~S} 6)$} & Yes & 5.38 & 6.564 & 0.000 & 13 (S7) & Yes & 4.17 & 1.119 & 0.268 \\
\hline & No & 2.06 & & & & No & 3.43 & & \\
\hline \multirow[t]{2}{*}{4 (S4) } & Yes & 1.75 & 0.040 & 0.968 & 14 (S5) & Yes & 2.79 & -1.222 & 0.227 \\
\hline & No & 1.73 & & & & No & 3.63 & & \\
\hline \multirow[t]{2}{*}{5 (S5) } & Yes & 2.30 & -1.997 & 0.051 & $15(\mathrm{~S} 1)$ & Yes & 4.20 & -2.293 & 0.025 \\
\hline & No & 3.60 & & & & No & 5.62 & & \\
\hline \multirow[t]{2}{*}{$6(\mathrm{~S} 5)$} & Yes & 2.09 & 0.712 & 0.479 & $17(\mathrm{~S} 3)$ & Yes & 3.50 & 0.495 & 0.623 \\
\hline & No & 1.73 & & & & No & 3.19 & & \\
\hline \multirow[t]{2}{*}{7 (S1) } & Yes & 4.31 & -2.497 & 0.015 & $18(\mathrm{~S} 2)$ & Yes & 4.94 & 0.023 & 0.982 \\
\hline & No & 5.83 & & & & No & 4.92 & & \\
\hline \multirow[t]{2}{*}{$9(\mathrm{~S} 2)$} & Yes & 3.23 & -1.685 & 0.097 & 19 (S6) & Yes & 2.58 & 0.82 & 0.935 \\
\hline & No & 4.32 & & & & No & 2.54 & & \\
\hline \multirow[t]{2}{*}{$10(\mathrm{~S} 7)$} & Yes & 2.64 & 0.896 & 0.374 & $21(\mathrm{~S} 1)$ & Yes & 2.90 & -1.321 & 0.192 \\
\hline & No & 2.20 & & & & No & 3.75 & & \\
\hline \multirow[t]{2}{*}{$12(\mathrm{~S} 4)$} & Yes & 2.17 & 0.617 & 0.540 & & & & & \\
\hline & No & 1.84 & & & & & & & \\
\hline
\end{tabular}

Through a repeated-measures analysis of variance, the influence of each type of script interruption on the degree of satisfaction was compared. Measures were significantly different $(\mathrm{F}=17.511, \mathrm{p}=0.000)$. In table 4 results of comparison among different types of interruptions are presented. The degree of satisfaction associated to script interruptions varies for all categories, except for differences between S6 (Error) and S5 (Obstacle) ( $\mathrm{p}=0.450)$; S5 (Obstacle) and S3 (successfully solved obstacle) $(\mathrm{p}=0.063)$, or between S1 (successfully solved obstacle) and S2 (successfully solved 
error) $(p=0.057)$. An increase of estimated means of satisfaction can be observed in table 4 when approaching a positive outcome of the script interruption. The unsuccessfully solved error category produces the lowest degree of satisfaction with a means score of 1.833 while the successfully solved error category produces the highest degree of satisfaction with a means score of 4.933 .

Table 4. Comparison of satisfaction scores associated to each type of script interruption. Script interruption categories are organized in ascending order according to the estimated means.

\begin{tabular}{|c|c|c|c|c|c|c|}
\hline Type of script interruption & $\bar{X}_{1}$ & Compared to type of interruption & $\bar{X}_{2}$ & $\bar{X}_{1}-\bar{X}_{2}$ & $S E$ & $p$ \\
\hline \multirow[t]{6}{*}{ S4: Unsuccessfully solved error } & \multirow[t]{6}{*}{1.883} & S6: Error & 2.317 & -0.433 & 0.155 & 0.007 \\
\hline & & S5: Obstacle & 2.472 & -0.589 & 0.136 & 0.000 \\
\hline & & S3: Unsuccessfully solved obstacle & 2.789 & -0.906 & 0.170 & 0.000 \\
\hline & & S7: Distraction & 3.339 & -1.456 & 0.202 & 0.000 \\
\hline & & S1: Successfully solved obstacle & 4.650 & -2.767 & 0.307 & 0.000 \\
\hline & & S2: Successfully solved error & 4.933 & -3.050 & 0.308 & 0.000 \\
\hline \multirow[t]{6}{*}{ S6: Error } & \multirow[t]{6}{*}{2.317} & S4: Unsuccessfully solved error & 1.883 & 0.433 & 0.155 & 0.007 \\
\hline & & S5: Obstacle & 2.472 & -0.156 & 0.204 & 0.450 \\
\hline & & S3: Unsuccessfully solved obstacle & 2.789 & -0.472 & 0.186 & 0.014 \\
\hline & & S7: Distraction & 3.339 & -1.022 & 0.193 & 0.000 \\
\hline & & S1: Unsuccessfully solved obstacle & 4.650 & -2.333 & 0.241 & 0.000 \\
\hline & & S2: Successfully solved error & 4.933 & -2.617 & 0.262 & 0.000 \\
\hline \multirow[t]{6}{*}{ S5: Obstacle } & \multirow[t]{6}{*}{2.472} & S4: Unsuccessfully solved error & 1.883 & 0.589 & 0.136 & 0.000 \\
\hline & & S6: Error & 2.317 & 0.156 & 0.204 & 0.450 \\
\hline & & S3: Unsuccessfully solved obstacle & 2.789 & -0.317 & 0.167 & 0.063 \\
\hline & & S7: Distraction & 3.339 & -0.867 & 0.215 & 0.000 \\
\hline & & S1: Successfully solved obstacle & 4.650 & -2.178 & 0.304 & 0.000 \\
\hline & & S2: Successfully solved error & 4.933 & -2.461 & 0.308 & 0.000 \\
\hline \multirow[t]{6}{*}{ S3: Unsuccessfully solved obstacle } & \multirow[t]{6}{*}{2.789} & S4: Unsuccessfully solved error & 1.883 & 0.906 & 0.170 & 0.000 \\
\hline & & S6: Error & 2.317 & 0.472 & 0.186 & 0.014 \\
\hline & & S5: Obstacle & 2.472 & 0.317 & 0.167 & 0.063 \\
\hline & & S7: Distraction & 3.339 & -0.550 & 0.203 & 0.009 \\
\hline & & S1: Successfully solved obstacle & 4.650 & -1.861 & 0.271 & 0.000 \\
\hline & & S2: Successfully solved error & 4.933 & -2.144 & 0.268 & 0.000 \\
\hline \multirow[t]{6}{*}{ S7: Distraction } & \multirow[t]{6}{*}{3.339} & S4: Unsuccessfully solved error & 1.883 & 1.456 & 0.202 & 0.000 \\
\hline & & S6: Error & 2.317 & 1.022 & 0.193 & 0.000 \\
\hline & & S5: Obstacle & 2.472 & 0.867 & 0.215 & 0.000 \\
\hline & & S3: Unsuccessfully solved obstacle & 2.789 & 0.550 & 0.203 & 0.009 \\
\hline & & S1: Successfully solved obstacle & 4.650 & -1.311 & 0.250 & 0.000 \\
\hline & & S2: Successfully solved error & 4.933 & -1.594 & 0.243 & 0.000 \\
\hline \multirow[t]{6}{*}{ S1: Successfully solved obstacle } & \multirow[t]{6}{*}{4.650} & S4: Unsuccessfully solved error & 1.883 & 2.767 & 0.307 & 0.000 \\
\hline & & S6: Error & 2.317 & 2.333 & 0.241 & 0.000 \\
\hline & & S5: Obstacle & 2.472 & 2.178 & 0.304 & 0.000 \\
\hline & & S3: Unsuccessfully solved obstacle & 2.789 & 1.861 & 0.271 & 0.000 \\
\hline & & S7: Distraction & 3.339 & 1.311 & 0.250 & 0.000 \\
\hline & & S2: Successfully solved error & 4.933 & -0.283 & 0.146 & 0.057 \\
\hline \multirow[t]{6}{*}{ S2: Successfully solved error } & \multirow[t]{6}{*}{4.933} & S4: Unsuccessfully solved error & 1.883 & 3.050 & 0.308 & 0.000 \\
\hline & & S6: Error & 2.317 & 2.617 & 0.262 & 0.000 \\
\hline & & S5: Obstacle & 2.472 & 2.461 & 0.308 & 0.000 \\
\hline & & S3: Unsuccessfully solved obstacle & 2.789 & 2.144 & 0.268 & 0.000 \\
\hline & & S7: Distracción & 3.339 & 1.594 & 0.243 & 0.000 \\
\hline & & S1: Obstáculo resolución positiva & 4.650 & 0.283 & 0.146 & 0.057 \\
\hline
\end{tabular}




\section{Representation of a high quality establishment}

Descriptive statistics corresponding to the second phase of the study (how well the situations represent the quality of a cafeteria) are shown in Table 5. S2 (successfully solved error) with a means score of $5.19(\mathrm{SD}=1.17)$; S4 (unsuccessfully solved error) with a means score of 5.06 ( $\mathrm{SD}=2.08)$; S1 (successfully solved obstacle) and S3 (unsuccessfully solved obstacle) both with a means score of $5.04(\mathrm{SD}=1.26)$ were the three most representative situations of quality. Thus, those categories with both a positive outcome and a negative outcome are in the group of categories that represent best service quality. Categories located in an intermediate position were the ones that were unsolved, that is to say: S5 (Obstacle) with a means score of $4.34(\mathrm{SD}=1.59)$ and S6 (Error) with a means score of $4.79(\mathrm{SD}=1.81)$. The category that represented a quality service least was S7 (Distraction) with a means score of $3.45(\mathrm{SD}=1.41)$.

Table 5. Descriptive statistics for phase two: quality representation assessment.

\begin{tabular}{lcccc}
\multicolumn{1}{c}{ Categories } & Min & Max & $\bar{X}$ & SD \\
\hline S7: Distraction & 1 & 7 & 3.45 & 1.41 \\
S5: Obstacle & 1 & 7 & 4.34 & 1.59 \\
S6: Error & 1 & 7 & 4.79 & 1.81 \\
S1: Obstacle- successfully solved & 2 & 7 & 5.04 & 1.26 \\
S3: Obstacle-unsuccessfully solved & 2 & 7 & 5.04 & 1.26 \\
S4: Error-unsuccessfully solved & 1 & 7 & 5.06 & 2.08 \\
S2: Error-successfully solved & 3 & 7 & 5.19 & 1.17 \\
\hline
\end{tabular}

Next, a $T$ test was used to establish if those questions with significant differences in the occurrence answers showed, in turn, differences in the obtained means. In table 6 results of this analysis are shown. None of the situations that had showed differences in terms of its occurrence showed differences in how representative they were of a quality establishment.

Table 6. T test to evaluate means differences of quality representativity in questions with significant differences in terms of occurrence.

\begin{tabular}{lcccccccccc}
\hline & & & & & & & & & \\
Question & Occurrence option & $\bar{X}$ & $T$ & $p$ & Question & Occurrence option & $\bar{X}$ & $T$ & $p$ \\
\hline 2 (S6) & Yes & 4.46 & 0.532 & 0.597 & 13 (S7) & Yes & 3.67 & -0.705 & 0.484 \\
& No & 4.16 & & & & No & 4.09 & & \\
4 (S4) & Yes & 5.32 & 0.204 & 0.839 & 14 (S5) & Yes & 4.46 & 1.222 & 0.227 \\
& No & 5.19 & & & & No & 3.78 & & \\
5 (S5) & Yes & 5.21 & 1.367 & 0.177 & 15 (S1) & Yes & 4.68 & -1.966 & 0.055 \\
& No & 4.41 & & & & No & 5.72 & & \\
6 (S5) & Yes & 3.82 & -1.037 & 0.304 & 17 (S3) & Yes & 4.44 & 0.853 & 0.397 \\
& No & 4.41 & & & & No & 4.00 & & \\
7 (S1) & Yes & 5.54 & -1.201 & 0.236 & 18 (S2) & Yes & 4.79 & 0.842 & 0.403 \\
& No & 6.06 & & & & No & 4.32 & & \\
9 (S2) & Yes & 4.86 & -0.161 & 0.873 & 19 (S6) & Yes & 5.14 & 0.515 & 0.609 \\
& No & 4.94 & & & & No & 4.84 & & \\
10 (S7) & Yes & 3.96 & -0.478 & 0.635 & 21 (S1) & Yes & 4.29 & 0.367 & 0.715 \\
& No & 4.25 & & & & No & 4.09 & & \\
12 (S4) & Yes & 4.89 & -0.520 & 0.605 & & & & & \\
& No & 5.22 & & & & & & & & \\
\hline
\end{tabular}

Again, through a repeated-measures analysis of variance, each script interruption was compared to each other in order to determine if they differed in how well they represented a quality establishment. Results were significantly different $(\mathrm{F}=12.165, \mathrm{p}=0.000)$. In addition, as it is shown in table 7 , differences among categories are significant, except between S5 (Obstacle) and S6 (Error) $(\mathrm{p}=0.058)$; S6 (Error) and S3 (unsuccessfully solved obstacle) $(p=0.309)$, with S1 (successfully solved obstacle) $(p=0.309)$, with S4 (unsuccessfully solved error) $(\mathrm{p}=0.178)$ and S2 (successfully solved error) ( $\mathrm{p}=0.131)$; S3 (unsuccessfully solved obstacle) and S4 (unsuccessfully solved error) $(p=0.970)$ and S2 (successfully solved error) ( $\mathrm{p}=0.469)$; S1 (successfully solved obstacle) and S4 (unsuccessfully solved error) $(\mathrm{p}=0.970)$ and S2 (successfully solved error) $(\mathrm{p}=0.469)$ and finally between S4 (unsuccessfully solved error) and S2 (successfully solved error $)(p=0.654)$.

\section{DISCUSSION}

This work shows the differences in consumer affective judgments when different script interruption categories take place. It also mirrors the results obtained by Falces, et al., (2002) with a Spanish sample and it corroborates what Schank and Abelson (1977) exposed about script interruptions and the consequent affective responses. Unsolved or unsuccessfully solved errors and obstacles (S4, S6, S5, S3) caused a more negative judgment than those successfully solved (S1, S2) (Table 1). Distractions are situated in an intermediate position (S7) meaning that satisfaction with the result does not depend only on the possibility to carry out the actions in the script but also on consumer's decision making, which, in this case, decides whether to abandon the script or not.

Successfully or unsuccessfully solved errors (S2 or S4) differ from successfully or unsuccessfully solved obstacles (S1 o S3), respectively. However, unsolved errors (S6) do not differ from unsolved obstacles (S5) (Table 4). This finding is different from the one obtained by Falces, et. al. (2002) who did not find differences between obstacles and errors, both unsuccessfully solved. Additionally, the distraction category also showed a difference with the study by Falces, et al. In our study, such category was significantly different from the others while in the Spanish study this category did not yield a significant different affective judgment from the successfully solved error category (S2), although it did with the others. Based on these results it is possible to assert that, from our study, there are differences in affective judgment produced by successfully or unsuccessfully solved obstacles, successfully or unsuccessfully solved errors and distractions.

On the other hand, it has been said that consumers express highly negative judgments in response to categories with undesirable outcomes, as if unpleasant experiences had a stronger representation in memory (Schank, 1980). Due to the relation of consumer's negative affects with other variables (Yi \& Gong, 2006), it is thus important to handle these es 
properly. However, after checking the occurrence or not of the situations listed in the questionnaire, only those in the "obstacle" category had been experienced by all participants. Two out of the three questions in the "distraction" category (Table 2) follow this same pattern and consequently these are the only two categories participants were able to evoke. According to the above mentioned analysis, the rest of the questions reflect unusual situations for participants and it cannot be said that the satisfaction they attribute to them is the result of an actual experience but the consequence of a hypothesis about what such an experience would be like. So their responses to these situations do not reflect a pure judgment in a new situation, as Kotler proposed (1996) and they are not the result of a habit, as Múgica and Ruiz indicated (1997). Likewise, based on our study, since the situations include both with positive and negative outcomes, we cannot support Schank's findings (1980) in the sense that a differential printing of negative outcomes would take place in memory. Our results also differ from the ones obtained in other studies where a differential effect for positive and negative affect has been proposed (depending on the type of population; Alden, De la Cruz, \& Viboonsanti, 2004). Consequently, the only conclusion we can draw is that distractions produce a higher degree of satisfaction than obstacles.

Table 7. Comparison among quality representativity scores. Script interruptions categories are organized in ascendant order according to the estimated means.

\begin{tabular}{|c|c|c|c|c|c|c|}
\hline Script interruption & $\bar{X}_{1}$ & Compared to the type of interruption & $\bar{X}_{2}$ & $\bar{X}_{1}-\bar{X}_{2}$ & $S E$ & $P$ \\
\hline \multirow[t]{6}{*}{ S7: Distraction } & \multirow[t]{6}{*}{3,450} & S5: Obstacle & 4.339 & -0.889 & 0.244 & 0.001 \\
\hline & & S6: Error & 4.794 & -1.344 & 0.302 & 0.000 \\
\hline & & S3: Unsuccessfully solved obstacle & 5.044 & -1.594 & 0.264 & 0.000 \\
\hline & & S1: Successfully solved obstacle & 5.044 & -1.594 & 0.264 & 0.000 \\
\hline & & S4: Unsuccessfully solved error & 5.056 & -1.606 & 0.315 & 0.000 \\
\hline & & S2: Successfully solved error & 5.194 & -1.744 & 0.230 & 0.000 \\
\hline \multirow[t]{6}{*}{ S5: Obstacle } & \multirow[t]{6}{*}{4,339} & S7: Distraction & 3.450 & 0.889 & 0.244 & 0.001 \\
\hline & & S6: Error & 4.794 & -0.456 & 0.236 & 0.058 \\
\hline & & S3: Unsuccessfully solved obstacle & 5.044 & -0.706 & 0.265 & 0.010 \\
\hline & & S1: Successfully solved obstacle & 5.044 & -0.706 & 0.265 & 0.010 \\
\hline & & S4: Unsuccessfully solved error & 5.056 & -0.717 & 0.243 & 0.005 \\
\hline & & S2: Successfully solved error & 5.194 & -0.856 & 0.242 & 0.001 \\
\hline \multirow[t]{6}{*}{ S6: Error } & \multirow[t]{6}{*}{4,794} & S1: Distraction & 3.450 & 1.344 & 0.302 & 0.000 \\
\hline & & S5: Obstacle & 4.339 & 0.456 & 0.236 & 0.058 \\
\hline & & S3: Unsuccessfully solved obstacle & 5.044 & -0.250 & 0.244 & 0.309 \\
\hline & & S1: Successfully solved obstacle & 5.044 & -0.250 & 0.244 & 0.309 \\
\hline & & S4: Unsuccessfully solved error & 5.056 & -0.261 & 0.191 & 0.178 \\
\hline & & S2: Successfully solved error & 5.194 & -0.400 & 0.261 & 0.131 \\
\hline \multirow[t]{6}{*}{ S3: Unsuccessfully solved obstacle } & \multirow[t]{6}{*}{5,044} & S7: Distraction & 3.450 & 1.594 & 0.264 & 0.000 \\
\hline & & S5: Obstacle & 4.339 & 0.706 & 0.265 & 0.010 \\
\hline & & S6: Error & 4.794 & 0.250 & 0.244 & 0.309 \\
\hline & & S1: Successfully solved obstacle & 5.044 & 0.000 & 0.000 & \\
\hline & & S4: Unsuccessfully solved error & 5.056 & -0.011 & 0.292 & 0.970 \\
\hline & & S2: Successfully solved error & 5.194 & -0.150 & 0.206 & 0.469 \\
\hline \multirow[t]{6}{*}{ S1: Successfully solved obstacle } & \multirow[t]{6}{*}{5,044} & S7: Distraction & 3.450 & 1.594 & 0.264 & 0.000 \\
\hline & & S5: Obstacle & 4.339 & 0.706 & 0.265 & 0.010 \\
\hline & & S6: Error & 4.794 & 0.250 & 0.244 & 0.309 \\
\hline & & S3: Unsuccessfully solved obstacle & 5.044 & 0.000 & 0.000 & \\
\hline & & S4: Unsuccessfully solved error & 5.056 & -0.011 & 0.292 & 0.970 \\
\hline & & S2: Successfully solved error & 5.194 & -0.150 & 0.206 & 0.469 \\
\hline \multirow[t]{6}{*}{ S4: Unsuccessfully solved error } & \multirow[t]{6}{*}{5,056} & S7: Distraction & 3.450 & 1.606 & 0.315 & 0.000 \\
\hline & & S5: Obstacle & 4.339 & 0.717 & 0.243 & 0.005 \\
\hline & & S6: Error & 4.794 & 0.261 & 0.191 & 0.178 \\
\hline & & S3: Unsuccessfully solved obstacle & 5.044 & 0.011 & 0.292 & 0.970 \\
\hline & & S1: Successfully solved obstacle & 5.044 & 0.011 & 0.292 & 0.970 \\
\hline & & S2: Successfully solved error & 5.194 & -0.139 & 0.308 & 0.654 \\
\hline \multirow[t]{6}{*}{ S2: Successfully solved error } & \multirow[t]{6}{*}{5,194} & S7: Distraction & 3.450 & 1.744 & 0.230 & 0.000 \\
\hline & & S5: Obstacle & 4.339 & 0.856 & 0.242 & 0.001 \\
\hline & & S6: Error & 4.794 & 0.400 & 0.261 & 0.131 \\
\hline & & S3: Unsuccessfully solved obstacle & 5.044 & 0.150 & 0.206 & 0.469 \\
\hline & & S1: Successfully solved obstacle & 5.044 & 0.150 & 0.206 & 0.469 \\
\hline & & S4: Unsuccessfully solved error & 5.056 & 0.139 & 0.308 & 0.654 \\
\hline
\end{tabular}


However, it is worth noticing that the satisfaction measure used by Falces, et al. (2002) and us is different from the one traditionally used in building satisfaction questionnaires (c.f. Copeland, Koeske, \& Greeno, 2004; King \& Bond, 2003; McMurtry \& Hudson, 2000; Terblanche \& Boshoff, 2006).

Additionally, given that (1) subjective satisfaction equals the service perception minus the previous expectations level (Kotler, 1996), (2) knowledge of an event sequence influences the reaction to it (Falces, et al., 2002) and that (3) in every day life events expectations remain unchanged (Múgica \& Ruiz, 1997), a difference in judgments between people who have already experienced similar situations and those who have not is likely to exist. This is explained by the fact that the former are familiar with the sequence of events likely to happen and have made pleasant or unpleasant associations with the situation while the latter have not (Kotler, 1996). In our study, out of the 21 situations or script interruptions listed in the questionnaire only 8 significantly represent a situation not experienced by participants (Table 2). On the contrary, participants were significantly familiar with 7 situations. The rest of the situations showed an approximately similar distribution. In theory, these results should produce differential affective judgments, but, as it is observed in Table 3 , such differences did not appear, except for situation 2 (Error category), 7 and 15 (both in the successfully solved obstacle category). Therefore, in general, an effect of novelty or familiarity of a situation on affective judgments is not observed.

Regarding the extent to which the situations represent a quality establishment a considerable difference is observed between the distraction category (the lowest score) and the other categories (Table 5). The greatest difference is observed between "distraction" and "obstacle" and between "obstacle" and "error". The remaining categories do not show a significant difference among each other. According to these data, successfully or unsuccessfully solved errors and obstacles are equally representative of a quality establishment while distractions are the least representative category. For users thus what represents quality is not merely the extent to which the service can solve the problems encountered (Zeithaml, et al., 1995). This finding heavily differs from the one obtained by Falces, et al. (2002), where these categories show similar results in terms of satisfaction in the Spanish sample. Even if our participants had developed a great adaptation to each situation (Quintanilla, 1999) no differences between situations that were familiar for participants and those which were not (Table 6) were found, and therefore this is not a proper explanation. However, results could be explained by the fact that consumption experience of participants in other establishments might have been similar and this might not allowed them to discriminate among quality representative situations.

Finally, although the obtained results have not corroborated findings by Falces, et al., (2002) about quality representation, they coincide more regarding the relation between affective judgments and script interruptions. This could be explained by the fact that these judgments are related to universal categories such as pleasant or unpleasant sensations, while the evaluation of situations as representative of quality is rather associated to cultural aspects of the studied population. These cultural variables are part of the consumer behavior (Schiffman \& Lazar, 1996) and their evaluation requires the design of real transcultural valid tools (Witkowski \& Wolfinbarger, 2002), but it makes the construction of an integral quality management system difficult as proposed in specific contexts (Bickman, Riemer, Breda, \& Kelley, 2006; Torbica \& Stroh, 1999).

\section{REFERENCES}

Alden, D. L., De la Cruz, J., \& Viboonsanti, P. (2004). Influences on Client Loyalty to Reproductive Health-Care Clinics in the Philippines and Thailand. Asian-Pacific Population Journal, 19(4), 9-24.

Arcas, G., \& Cano, V. (1999). Procesos cognitivos en el trastorno de ansiedad generalizada, según el paradigma del procesamiento de la información, Psicothema, 3(1), 145-149.

Arellano, R. (1993). Comportamiento del consumidor y Marketing. México, D. F., México: Harla.

Barranco, C. (2002). Calidad del servicio: Estudio realizado en CAMPs de Tenerife. Intervención Psicosocial, 11(3), 371-382.

Berne, C., Pedraja, M., \& Rivera, P. (1997) El comportamiento de búsqueda de precios de los consumidores. Revista Española de la Investigacióny Marketing, ESIC, 1, 45-62.

Bickman, L., Riemer, M., Breda, C., \& Kelley, S. D. (2006). CFIT: A System to Provide a Continuous Quality Improvement Infrastructure Through Organizational Responsiveness, Measurement, Training, and Feedback. Report on Emotional \& Behavioral Disorders in Youth, 6(4), 8694).

Bower, G. H., Black, J. B., \& Turner, T. J. (1979). Scripts in memory for texts. Cognitive Psychology, 11, 177-220.

Bronfman, M. N., López, S., Magis, C., More, A., \& Rutstein, S. (2003). Atención prenatal en el primer nivel de atención: características de los proveedores que influyen en la satisfacción de las usuarias. Salud Pública de México, 45, 445454.

Caminal, J. (2001). La medida de la satisfacción un instrumento de participación de la población en la mejora de la calidad de los servicios sanitarios. Revista de Calidad Asistencial, 16, 276-279.

Certo, S. C. (2001). Administración Moderna. (8a Ed.). Bogotá, Colombia: Pearson Education.

Copeland, V. C., Koeske, G., \& Greeno, C. G. (2004). Child and Mother Client Satisfaction Questionnaire Scores Regarding Mental Health Services: Race, Age, and Gender Correlatos Research on Social Work Practice. Research on Social Work Practice, 14, 434-442.

Davidson, D., \& Jergovic, D. (1996). Children's memory for atypical actions in script-based stories: An examination of the disruption effect. Journal of Experimental Child Psycholgy, 61, 134-152. 
Di Mare, A. (1992, Octubre). Teoría del comportamiento del consumidor, Acta Académica, Universidad Autónoma de Centro América, 11, 71-77.

Falces, C., Sierra, B., Briñol, P., \& Horcajo, J. (2002). Alteraciones del script y juicios afectivos: satisfacción del consumidor. Psicothema, 14(3), 623-629.

García, O. J. (1997). Un modelo de las interacciones matónvíctima. Anales de Psicología, 13(1), 51-56.

Garman, A. N., Corrigan, P. W., \& Morris, S. (2002). Staff Burnout and Patient Satisfaction: Evidence of Relationships at the Care Unit Level. Journal of Occupational Health Psychology, 7(3), 235-241.

Gattinara, B. C., Ibacache, J., Puente, C. T., Giaconi, J., \& Caprara, A. (1995). Percepción de la Comunidad Acerca de la Calidad de los Servicios de Salud Públicos en los Distritos Norte e lchilo, Bolivia. Cadernos de Saúde Pública, 11(3), 425-438.

Gea, M. T., Hernán, M., Jiménez, J. M., \& Cabrera, A. (2001). Opinión de los usuarios sobre la Calidad del Servicio de Urgencias del Centro Médico-Quirúrgico del Hospital Virgen de las Nieves. Revista de Calidad Asistencial, 16, 37-44.

Gil, A., Feliu, J., \& Lajeunesse, S. (coords.). (2004). Psicología económica y del comportamiento del consumidor. Barcelona, España: UOC.

Hayes, B. E. (1999). Cómo medir la satisfacción del cliente. Madrid, España: Oxford University Press.

Horovitz, J. (1992). La calidad del servicio. Madrid, España: McGraw-.Hill.

Johnson-Laird, P. N. (1980). Modelos mentales en ciencia cognoscitiva. Ciencia Cognoscitiva, 4, 71-115.

King, J. A., \& Bond, T. G. (2003). Measuring Client Satisfaction with Public Education I. Meeting Competing Demands in Establishing State-wide Benchmarks. Journal of Applied Measurement, 4(2), 111-123.

Kotler, P. (1996). Dirección de Mercadotecnia (8ª ed.) México, D. F., México: Prentice Hall.

León, J. L., \& Olabarría, E. (1991). Conducta del Consumidor y Marketing. México, D. F., México: Deusto.

Luna, A. (2001): Marketing y deporte: la escala MODE de motivaciones deportivas. Revista Digital, 7(35), 1. Recuperado el 6 de Junio de 2007, de http://www.efdeportes. com/efd35/mode.htm

Mandler, J. M. (1984). Stories, script and scenes: aspects of schema theory. Hillsdale, USA: Erlbaum.

Mazo, J. C., Martínez, V., Ramos, J., \& Peiró, J. M. (2002). La satisfacción del usuario desde el modelo de la confirmación de expectativas: respuesta a algunos interrogantes. Psicothema, 14(4), 765-770.

McMurtry, S. L., \& Hudson, W. W. (2000). The Client Satisfaction Inventory: Results of an Initial Validation Study. Research on Social Work Practice, 10(5), 644-663.

Múgica, J. M., \& Ruiz, M. S. (1997). El Comportamiento del Consumidor. Madrid, España: Ariel.

Quintanilla, L. (1999). Técnicas y procedimientos de intervención en psicología del consumidor. Madrid, España: McGraw-Hill.

Ruíz, V. J. M. (1997). Claves de la Memoria. Madrid, España: Trotta.
Rumelhart, D. E. (1984). Schemata and the cognitive sistem. En R. S. Wyer, \& T. K. Srull (Eds.), Handbook of Social Cognition. Vol. 1 (pp. 161-188). Hillsdale, USA: Erlbaum.

Rumelhart, \& McClelland, (1992). Introducción al procesamiento distribuido en paralelo. Madrid, España: Alianza.

Salvador, C. (2004). La visión humanista de los servicios universitarios. Almería, España: Universidad de Almería. Servicio de Publicaciones.

Salvador, C. M. (2005a). Validez predictiva de los componentes del compromiso del cliente y su relación con la satisfacción. Anales de Psicología, 21(2), 316-322.

Salvador, C. M. (2005b). Evaluación de la calidad de servicios en España y Paraguay y su impacto en la satisfacción de los usuarios. Apuntes de Psicología, 23(1), 71-82.

Schank, R. C. (1980). Languaje and memory. Cognitive Science, 4, 243-284.

Schank, R. P., \& Abelson, R. (1977). Guiones, planes, metas y entendimiento: un estudio de las estructuras del conocimiento bumano. Barcelona, España: Paidos Ibérica.

Schiffman, L. G., \& Lazar, K. L. (1996). El comportamiento del consumidor (5 ${ }^{\mathrm{a}}$ ed.), México, D. F., México: Prentice Hall.

Sierra, B., Falces, C., Ruiz, M. A., \& Alier, E. (2003). Estructura de la calidad percibida en servicios de hostelería con clientelas cautivas. ESIC Market, 116, 21-44.

Soler, M. P., Llobel, J. P., Frías, M. D., \& Rosel, J. (2006). Calidad de servicio en supermercados: una propuesta de medición. Psicothema, 18(3), 661-667.

Terblanche, N. S., \& Boshoff, C. (2006). A generic instrument to measure customer satisfaction with the controllable elements of the in-store shopping experience. South African Journal of Business Management, 37(3), 1-16.

Torbica, Z. M., \& Stroh, R. C. (1999). An Assessment model for Quality Performance Control in Residential Construction. Journal of Construction Education, 4(3), 332340.

Varela, J., Prat, R., Voces, C., \& Rial, A. (2006). Una nueva escala para la evaluación de la calidad de los servicios de hostelería. Psicothema, 18(1), 135-142.

Vázquez, R., Díaz, A., \& Rodríguez, I. (1997). Calidad de servicio y satisfacción del consumidor. Un enfoque multidimensional para empresas de supermercados. Información Comercial Española, Revista de Economia, 763, 120137.

Williams, B. (1994). Patient satisfaction: a valid concept?. Social Science \& Medicine, 38, 509-516.

Witkowski, T. H., \& Wolfinbarger, M. F. (2002). Comparative service quality: German an American ratings across service settings. Journal of Business Research, 55, 875-881.

Yi, Y., \& Gong, T. (2006). The Antecedents and Consequences of Service Customer Citizenship and Badness Behavior. Seoul Journal of Business, 12(2), 145-176.

Zeithaml, V., Parasuraman, A., \& Berry, L. (1995). La calidad total en la gestión de servicios. Cómo lograr el equilibrio entre las percepciones y las expectativas de los consumidores. Madrid, España: Díaz de Santos. 